\title{
SELF-REGULATION AND SELF-REGULATORY CAPACITIES: COMPONENTS, LEVELS, MODELS
}

\author{
Galina V. Ozhiganova \\ Institute of Psychology of Russian Academy of Sciences \\ 13, Yaroslavskaya str., Moscow, 129366, Russian Federation
}

\begin{abstract}
In the article various definitions of self-regulation are considered. The task is to examine the notion of self-regulation and its perceptions in the Western and Russian psychology; the notion of self-regulatory capacities; the components, levels and models of self-regulation. A review of the representation of self-regulation in the Western and Russian psychology reveals that self-regulation is studied in relation to different facets of life: self-regulated learning, professional activity, health management, well-being, etc. Self-regulation is generally defined through the term "capacity" or "ability". It makes researchers comprehend the concept of self-regulatory capacities itself more deeply. The theoretical analysis of the components, levels and models of self-regulation allows us to speak about their variety, but there are the components which are general and crucial: motivation, standards (including values, morality), goal-setting, planning, ability for monitoring and self-control, capacity to evaluate and correct the results, to persist in goal attainment. It is revealed that a very important component of self-regulation - spiritual - is missing in the reviewed models, and the author proposes the two models of self-regulation where the spiritual level is included: 1) a four-level model of selfregulation; 2) a four-level model of self-regulation and self-regulatory capacities. Both models imply a higher spiritual level of self-regulation which is related to higher moral principles and based on the highest values and meanings of being. The higher self-regulatory capacities help to liberate the potential of energy for disinterested selfless service to the society. The higher self-regulatory capacities allow individuals to increase the energy resource for self-regulation and contribute to the productivity and quality of life.
\end{abstract}

Key words: self-regulation, components and levels of self-regulation, higher spiritual level of selfregulation, higher self-regulatory capacities, models of self-regulation

\section{Introduction}

The self-regulation questions are important for a psychological study, as they are related to the principal facets of human life. Social relevance and self-realization, professional success and family happiness, advancement to higher stages of personal development and spiritual growth are based on the capability for self-regulation.

Focused on the importance of the self-regulation in the human life and the necessity of its wide psychological study, the task of this research is to consider:

- the notion of self-regulation and its perceptions in the Western and Russian psychology;

— the notion of self-regulatory capacities;

- the components, levels and models of self-regulation. 


\section{Representation of self-regulation in Western and Russian psychology}

In dictionaries, self-regulation is interpreted according to the specialization, but as my interest lies with humanities, in the Dictionary of Sociology self-regulation is defined as:

1) The property of the systems of different levels to keep the inner stability thanks to its coordinated reactions, compensating for the influence of changing environmental conditions;

2) The activity aimed at achieving the goal arbitrary set by the person and suggesting the creation of the model of this activity, its correction during the activity (Dictionary of Sociology).

In the Psychological Dictionary (A Brief Dictionary of Psychological Terms), the self-regulation is defined as the process of the person managing their own psychological and physiological states, as well as actions.

In Oxford Dictionary of Sports Science and medicine, the self-regulation is defined as the regulation of one's own goal-oriented behavior without immediate external control (Kent, 2006).

In the Western psychology, self-regulation is considered by many psychologists in relation to human goal-oriented activities.

The self-regulation is involved in self-concordant goal setting and enactment and successful completion of the goal-oriented action in connection with motivational and behavioral processes (Carver \& Scheier, 1998).

Self-regulation is related to action control and to attention control and is considered as the ability to keep one's attention focused on a given goal despite distractions (Diehl, Semegon, \& Schwarzer, 2006).

Effective self-regulators proactively direct their strategies to achieve self-set goals (Zimmerman, 2002). Self-regulation is the process of unceasingly monitoring progress toward a goal, checking results, and redirecting unsuccessful efforts (Berk, 2003).

Self-regulation is linked to the internal and/or transactional processes, enabling a person to conduct goal-directed activities over time and across changing circumstances. Regulation supposes control of thought, affect, behavior, or attention through deliberate or automated applying of particular mechanisms and supportive meta-skills. Selfregulation endeavors to guide behavior via a particular path to a directed goal. Thus, self-regulation is characterized by the volitional factors, such as goal setting, selfmonitoring, activation and use of goals, discrepancy detection and implementation, self-evaluation, self-consequation, self-efficacy, meta-skills, boundary conditions, and self-regulation failure (Karoly, 1993).

According to A. Bandura, "Self-regulatory system lies at the very heart of causal processes. They not only mediate the effects of most external influences, but provide the very basis for purposeful action" (Bandura, 1991a, p. 248). Social cognitive theory assumes that social factors influence the system of self-regulation as well as internal factors. "Selfregulation is a multifaceted phenomenon operating through a number of subsidiary cognitive processes including self-monitoring, standard setting, evaluative judgment, self-appraisal, and affective self-reaction” (Bandura, 1991a, p. 282).

In the framework of social cognitive theory, many researches (Schunk, 1990; Zimmerman, Bonner, \& Kovach, 1996; Schunk, 2001; Zimmerman, 2001) were aimed 
at studying self-regulated learning. In this regard, self-regulation is defined as "the selfdirective process by which learners transform their mental abilities into academic skills" (Zimmerman, 2002, p. 65).

The term of self-regulation covers states and processes linked to the regulation of stress, moods, thoughts, attention, emotions and impulses (hunger, aggression, sexual arousal) (Gross, 2007). Thus, self-regulation is often associated with emotional regulation (Ochner \& Gross, 2005; Gross \& John, 2003; Tice \& Baumeister, 1993), emphasizing the emotional aspect of self-regulation.

Cognitive aspects of self-regulation were studied in relation to planning and goals implementation (Gollwitzer, Fujita, \& Oettingen, 2004), attention (Rueda, Posner \& Rothbart, 2011), willpower in a cognitive-affective process (Mischel \& Ayduk, 2004).

The term of self-regulation is described in connection to well-being (Baumann, Kaschel, \& Kuhl, 2005; Hofer, Busch \& Kartner, 2011) and to health management (Cameron \& Leventhal, 2003; Mann, de Ridder \& Fujita, 2013). The aspects of selfregulation, widely researched in the Western psychology are related to health management and well-being: eating disorders (Fischera \& Munsch, 2012), alcohol consumption (Hustad, Carey, Carey \& Maisto, 2009); sexual behavior (Ross \& Fontao, 2006); aggressive behavior (Ross, Fontao \& Schneider, 2007; Ross \& Fontao, 2007; Tittle, Ward \& Grasmick, 2003), etc.

The Russian psychology traditionally associates the study of self-regulation with human activities, and the activity-based approach. According to this approach, the conscious self-regulation is understood as a holistic system to set the goals and to manage achieving the goals of behavior and activities. This system is based on goal setting, modeling of the significant conditions of the goals achieving, actions programming, evaluation and correction of the results.

The activity-based approach to understanding and studying self-regulation proceeds from the theory of functional systems (Anokhin, 1970), which posits that a key factor contributing to the forming of functional systems is linked to obtaining useful results.

In the context of the activity-based theory from a psychological point of view, this means that the process of regulation is implicitly associated with obtaining a particular result, i.e. with achieving certain objectives of activities (Leontiev, 1975). The activitybased approach uses a methodological paradigm with the principles of hard external determinism of the psyche, proceeding from the philosophy of dialectical materialism (reflection theory).

The self-regulation processes also occur in the close unity with the processes of selfcontrol and are one of the mechanisms of high reliability of human activity, including the professional activity. There are many researches in the frame of psychology of work studying how self-regulation can contribute to success in professional activity: selfregulation process for adaptation to complex professional activity in extreme conditions (Dikaya, 2003); self-regulation processes in relation to stress affecting professional effectiveness (Bodrov, 2006); self-regulation in situations of professional stress (Leonova, 2007), etc.

Nowadays, according to Prygin (2009), it is possible to distinguish the three basic directions in the studies of conscious self-regulation of the personality: 1) psychic selfregulation of a functional state (Dikaya, 2003); 2) volitional self-regulation of behavior 
and activity (Ivannikov, 2010); 3) conscious mental self-regulation of voluntary activity (Konopkin, 2007). The individual style approach (Morosanova, 1998) can be added, as well as the study of the features of self-regulation of mental states (Prokhorov, 2005), the concept of regulatory experience (Osnitsky, 2000) and others.

It should be noted that in defining self-regulation there is a trend to move from the outer determination to the inner one and at the same time to maintain the idea of mental functioning integrality. It is possible to mark that the traditional paradigm shifts away from the hard external determinism. This is particularly evident in the conception of regulatory experience (Osnitsky, 2000). He also links regulatory experience with a targeted, projected, organized activity of a person, but includes an important system of subjective criteria and evaluative attitudes, feelings, and presents it as an open system which is enriched and perfected over a lifetime.

The conception of regulatory experience (Osnitsky, 2000) based on a holistic approach to the study of psychological facts allows to emphasize reflexive and value aspects, as well as conscious and unconscious feelings, in many ways determining everyday human behavior. These aspects are related, on the one hand, to the self-regulatory capacities, and, on the other hand, - to the inner experience and are extremely important for the psychological study of the versatility of the inner life of man and the revitalization of resources at various levels including spiritual.

Thus, it is possible to say that in the Western and Russian representation of selfregulation there are common ideas about self-control, goal setting and achieving activity, in the Western psychology there is a special interest in health management, well-being, self-regulated learning in the Russian psychology a particular attention is paid to selfregulation of work and professional activity. Very significant, to my mind, in self-regulation is the inner experience factor (Osnitsky, 2000), which allows to consider reflexive and value aspects of self-regulation. I think that inner experience category allows to consider a higher level of self-regulation and self-regulatory capacities, which are characterized by spirituality, moral-value feelings, reflexivity, deep awareness, etc.

\section{Self-regulatory capacities}

Researchers often use the term "capacity" to describe the self-regulation. Thus, according to (Baumeister \& Vohs, 2007), the self-regulation relates to the capacity for changing behavior in accordance with the standards, ideals or goals conditioned by the internal or public expectations.

Self-regulation capacity is linked to significant self-help skills allowing effectively to manage thoughts, feelings, actions and to attain goals while mastering a demanding environment (Gagnon, Durand-Bush \& Young, 2016).

Self-regulation is considered as a highly adaptive capacity, so self-regulation processes are relevant to disciplines that seek to contribute to people's physical health, psychological well-being, and job performance» (Kuhl, Kaz n, \& Koole, 2006). Good self-regulatory capacities help to succeed in school, work, relationships and mental health in general (Baumeister \& Vohs, 2007).

Self-regulation in education is linked to the ability of the students to monitor their own actions in relation to the learning process (Gonzalez, 2013). 
Self-regulation is connected with the ability of a person to change consciously his state. Among the main methods of self-regulation in this relation could be named: neuromuscular relaxation, autogenic training, ideomotor training, self-hypnosis, etc. (Encyclopedic dictionary).

Self-regulation can be understood as the general capacity of a person who acts as the subject of their purposeful activity, and as the process of realizing this ability in a certain activity and specific forms of communication (Konopkin, 2007).

Self-regulatory capacity refers to an individual's ability to exert control over their behavior, thoughts, and feelings. For example, the capacity to inhibit prejudice, make oneself feel better, or select healthy food. The capacity for self-regulation varies among individuals and may depend on the situational factors such as the experience of selfregulatory fatigue.

Self-regulatory capacity is, however, thought to be a limited resource that (1) is temporarily depleted by the exertions of self-control (an effect termed "ego-depletion") and (2) varies in strength from person to person (Cameron, Webb, 2013).

Thus, self-regulation means the ability to set goals, to monitor one's behavior so that it serves those goals, to adjust behavior if necessary, and to have enough willpower to persist until the goals are reached.

I think that the self-regulatory capacities should help manage and direct personal behavior and control desires, impulses and emotions in accordance with the rules of human interaction, so that achieving certain goals, or reaching certain ideals became possible.

The capacity for self-regulation is one of the crucial human characteristics. It is connected with reflection, self-awareness, emotional and volitional processes, goal setting, with the achievement of vital and important goals, leading to self-development and the realization of the meanings and purposes of life. So, in self-regulation it is possible to specify different components, aspects and levels. Among the components and levels of self-regulation, I also point out its higher level - spiritual.

To my mind, self-regulation at some level can be considered as the higher capacity, opening the way to spiritual growth, and inner experience is a factor, contributing to the manifestation of this capacity. Self-regulation is associated with the higher capacity when it relates to spirituality. To define the highest level of self-regulation and self-regulatory capacities when they are considered as spiritual capacities, I use the criterion of proximity to the spiritual Self. Spiritual capacities ensure the movement from the egocentric self (person thinking only of oneself, without the regard for the interest, beliefs, attitudes of others) to a spiritual Self, which is based on the moral-value foundation of the personality (humanity and altruism). Spirituality is understood as covering two aspects of life: religious and non-religious - the area of creativity, high morality, selfless, disinterested service to people and society, etc. (Ozhiganova, 2010; Ozhiganova, 2016).

\section{Components, levels and models of self-regulation and self-regulatory capacities}

Many researchers studied self-regulation processes in the framework of social cognitive theory and social learning theory focusing on different components and aspects of self- 
regulation: goal setting (Schunk, 1985, 1990), standard setting (Mischel \& Liebert, 1966), self-evaluation (Bandura \& Cervone, 1983), self-efficacy perceptions (Zimmerman \& Ringle, 1981; Bandura, 1982), willpower (Mischel \& Ayduk, 2004; Corno, 1989), motivational component Bandura,1991b), etc.

Bandura highlights three main components of self-regulative mechanism: (1) Selfobservation (self-monitoring of one's behavior, its determinants and effects); (2) Judgment of one's behavior in relation to personal standards and environmental circumstances; (3) Affective self-reaction (Bandura, 1991a).

In relation to the self-regulated learning the main components of executive control process which is necessary in order to accomplish complex academic tasks independently were pointed out:

- Coordinating metacognitive knowledge - regulating cognitive and metacognitive knowledge, understanding one's own knowledge, and thought process;

- Planning - using a deliberate and organized approach to perform a task;

- Monitoring - evaluating comprehension whilst carrying out a task, and verifying the effectiveness, testing, assessing and revising strategies;

- Detecting failure - while fulfilling a task, detecting when an error is made;

- Correcting failure - when an error is detected, going back and correcting it (Zimmerman, 2001).

According to R. Baumeister, et al., there are three basic components of self-regulation, "The first is commitment to standards. The second is monitoring of the self and its behaviors. The third is what is needed to change the self's responses. All are necessary for effective self-regulation. Hence a breakdown or problem with any one of them can produce failure at self-regulation" (Baumeister, Schmeichel \& Vohs, 2007, p. 22). Developing the ideas about the self-regulation, (Baumeister \& Vohs, 2007, p. 117) point out four components of self-regulation, adding motivation:

- Standards (that means to make changes, according to some standard, which should be clear and well-defined. Uncertain or conflicting standards do not promote effective self-regulation;

- Monitoring is linked to comparing the self with the standard and evaluating, how much the self is changed and what is needed for a further progress to achieve the goal;

- Willpower (changing the self is not easy and needs the self-regulatory strength or energy, which is a limited resource and after the time leads to the ego depletion;

- Motivation - concretely motivation to regulate the self.

The self-regulation is represented not only in various components, but also at different levels and models. The two main levels are pointed out: (1) physiological and (2) mental. There are various processes of self-regulation on both physiological and mental levels. Each of them has its own qualitatively specific energy and information manifestations, which are in a complex and inextricable relationship (Encyclopedic dictionary).

The self-regulation of purpose-focused activity emerges as the most general and essential function of the integral human psyche. In the processes of self-regulation the unity of the psyche is realized in a wide variety of conditionally distinguished separate levels, sides, features, functions, processes, etc. (Konopkin, 1995).

Some authors propose the model of the seven-level system of regulation in the frame of personality systems interactions (PSI) theory, representing a functional analysis of the 
personality architecture, which underlies human motivation and self-regulation (Kuhl, 2000, 2001; Kuhl \& Koole, 2004).

The main idea of PSI theory is the following: a human motivation and personality are mediated by a hierarchy of regulatory systems. This theory considers seven levels of regulation (Kaschel \& Kuhl, 2004), which can be condensed into three broad levels (see Table 1) (Kuhl, Kazén \& Koole, 2006).

Table 1

Levels and Systems of PSI (Kuhl, Kazén \& Koole, 2006)

\begin{tabular}{|c|c|c|}
\hline Theory Broad category & Level & Main systems \\
\hline Complex cognition & $\begin{array}{l}\text { (7) Self-government } \\
\text { (6) High-level cognition }\end{array}$ & $\begin{array}{l}\text { Self-regulation (EM) } \\
\text { Self-control (IM) } \\
\text { Parallel holistic processing (EM) } \\
\text { Sequential analytic processing (IM) }\end{array}$ \\
\hline Emotions and coping & $\begin{array}{l}\text { (5) Motives Power (EM) } \\
\text { (4) Emotional coping } \\
\text { (3) Affect }\end{array}$ & $\begin{array}{l}\text { Achievement (IM) } \\
\text { Affiliation (IBC) } \\
\text { OR } \leftarrow \text { Hippocampus } \rightarrow \text { EM } \\
\text { Positive (IBC) Inhibition Pos. (IM) } \\
\text { Negative (OR) Inhibition Neg. (EM) }\end{array}$ \\
\hline Elementary sensation and behavior & $\begin{array}{l}\text { (2) Temperament } \\
\text { (1) Simple cognitive operations }\end{array}$ & $\begin{array}{l}\text { Motor activation (IBC) } \\
\text { Sensory arousal (OR) } \\
\text { Motor programs (IBC) } \\
\text { Sensory categorisation (OR) }\end{array}$ \\
\hline
\end{tabular}

Notes. EM = Extension Memory; IM = Intention Memory; OR = Object Recognition; IBC = Intuitive Behavioral Control; $\leftarrow \rightarrow=$ Interaction between two systems. PSI theory assumes interactions among all systems, especially at higher levels. Only the main systems involved at each level are listed in the table.

Using the social cognitive theory in self-regulated learning, the authors pick out four levels: 1) observation, 2) emulation, 3) self-control, and 4) self-regulation (Schunk \& Zimmerman, 1997).

A social cognitive theoretical model of the development of self-regulatory competence signifies that the academic competence develops from the social origin and afterwards shifts to self-sources in a series of levels (Table 2) (Schunk \& Zimmerman, 1997).

Table 2

Social cognitive analysis of influences on student's self-regulatory development (Schunk \& Zimmerman, 1997)

\begin{tabular}{|c|c|c|}
\hline Levels of Development & Social Influences & Self-Influences \\
\hline $\begin{array}{l}\text { Observational } \\
\text { Imitative } \\
\text { Self-controlled } \\
\text { Self-regulated }\end{array}$ & $\begin{array}{l}\text { Models } \\
\text { Verbal description } \\
\text { Social guidance and feed-back }\end{array}$ & $\begin{array}{l}\text { Internal standards } \\
\text { Self-reinforcement } \\
\text { Self-regulatory processes } \\
\text { Self-efficacy beliefs }\end{array}$ \\
\hline
\end{tabular}

In accordance to Shanker (2012), who studies children's self-regulation in learning, in relation to stress, there are five levels of self-regulation in his model:

1) Biological - Arousal: Environmental stressors (e.g., visual, auditory);

2) Emotional - Modulating negative and positive emotions;

3) Cognitive - Sustaining and switching attention; 
4) Social - Mastering the skills of co-regulation;

5) Prosocial - Developing the empathy (Shanker, 2012).

The self-regulation is closely related to the self-consciousness. According to (Stolin, 1985), there are three levels of the self-consciousness process functioning: 1) constitutional (organismic), 2) social, and 3) personal.

I applied Stolin's idea about the three levels of self-consciousness functioning to the self-regulation system and pointed out three levels/components of self-regulation. Having analyzed a numerous representations of the self-regulation (components, levels, models), I decided that one of the most important components - spiritual - was missing there, and I added one more level - spiritual.

Thus, I propose a four-level model of self-regulation.

1. Constitutional (organismic) component - activation of organismic resources psychophysiological level of self-regulation:

This level involves the regulation and self-regulation of functional states, that includes the self-regulation of emotional and psychophysiological states and is related to the energy activation component of adaptation, providing the expenditure processes, recovery and rapid redeployment of resources in line with its strategy of adaptation and significant for the person's purposes, on the one hand, and, on the other hand, compensatory factors hindering the achievement of these goals.

2. Social component - activation of psychological resources for social interaction - sociopsychological level of self-regulation:

- Includes psychological regulation of professional activity or a variety of other tasks as the main function of adaptation in which the person's presence captures the rearrangements of cognitive systems activities, purpose-oriented programs, without which the effective social adaptation is not possible;

- Involves social interactions (e.g. interaction with any social environment, including the public benefit activities, as well as family relationships, relationships with colleagues and friends);

- Self-regulation on this level is largely due to social and regulatory rules, life experience (outer experience).

3. Personal component - activation of inner life experience resources - psychological level of self-regulation:

This level allows to note that human behavior and its regulation depends not only on bodily constitution and organismic functions, social and normative experience, but also on the person's own activity linked to the subjective categorization of conditions, to formation of meanings and goal setting, based on the self-attitude, subjective inner experience, values and meanings dominants.

\footnotetext{
4. Spiritual component - activation of spiritual resources - supra-psychological (spiritual) level of self-regulation:

This level is related to higher human values, existential life meanings and spiritual development; implies both non-religious and religious aspects. The spiritual level is associated with internal "work" on the analysis and design of one's own behavior related to the moral and spiritual growth in accordance with the highest morality standards and with unselfish behavior. That presupposes ego decentration - a movement from the selfcentered ego to the spiritual self, which is based on the unselfish altruistic self.
} 
I emphasize that the division into the described levels is rather conditional, because individuals manifest themselves in their behavior as a holistic system, admitting simultaneous action of all levels of self-regulation: constitutional (organismic), social, personal, spiritual, but these levels can be represented in different proportions. Higher levels can automatically promote regulation at a lower level, especially, at the organismic level.

Developing the representation of the self-regulation system I propose the four-level model of self-regulation and the four-level model of self-regulation and self-regulatory capacities in relation to professional-activity (Ozhiganova, 2016). In comparison with my previous model there are some changes in the content of the levels.

1. Psychophysiological level - the ability for the self-regulation of emotional and psycho-physiological states.

2. Socio-psychological level - the ability for the self-regulation in the process of social interaction.

\section{Psychological level:}

a) the ability to regulate activities;

b) the capacity for personal self-control and self-perfection;

c) the capacity to show willpower, mobilize energy.

4. Spiritual level - the highest capacity for the self-regulation conditioned by the orientation of the person to higher values and meanings of existence. The self-regulation at the highest spiritual level is considered in this research in connection with higher selfregulatory capacities, which contribute to self-realization of the person in professional activity.

1. Psychophysiological level - the ability for the self-regulation of the emotional and psychophysiological states: from the simple self-regulatory skills (individual ways to restore psycho-emotional balance and improve physical well-being if that becomes necessary in the process of professional activities, for example, attention switching, etc., and after work activities, for example: walks, listening to music, playing sports, etc.) - to the complex ones (using specialized methods of self-regulation, for example, the currently actual and popular psychotechnics of yoga, Buddhism, etc.).

Using special techniques (methods) of self-regulation, corresponding to the particularities of the profession in difficult and extreme conditions of professional activity.

At this level, a person carries out the self-regulation free of social interaction, being all alone.

2. Socio-psychological level - the ability for self-regulation in the process of social interaction directly related to the professional activities, as well as during any social interaction that indirectly affects the success of professional activities (for example, family relations, relationships with friends, etc.). It includes previous level 1 in the social context of the professional activities and communication (herewith using social strategies for self-regulation of emotional and psychophysiological states).

The self-regulation in this case is largely due to socio-normative rules and life experience.

\section{Psychological level:}

a) the ability to regulate activities: goal-setting, planning, designing the necessary conditions for the performance of professional activities and ways to improve its 
effectiveness; ability for monitoring and self-control of its implementation success (high level of awareness at all stages of professional activity: motive - goal - necessary conditions - course of action - result evaluation - necessary correction - new result); is associated with intellectual reflection;

b) the ability for personal self-regulation and self-perfection (the development of selfawareness, self-knowledge in order to achieve the inner harmony necessary for a successful fulfillment of any professional activity). A personal reflection plays a decisive role, making it possible to understand a weak and strong character traits and regulate personal characteristics, motivational and need spheres in accordance with the requirements of a chosen professional activity; is associated with personal reflection;

c) the capacity to show willpower, mobilize energy for self-regulation; involves volitional efforts to achieve the goal of activity and the aim of self-perfection.

The ability for personal self-regulation in a developed form can be attributed to the category of higher self-regulatory capacities, as it creates conditions for the spiritual development and self-realization of a person in any activity, including professional activity.

4. Spiritual level - the highest capacity for self-regulation (associated with the holistic self-regulation at all levels, is conditioned by the highest values and meanings of being, relates to higher moral principles). The implementation of professional activity at this level is focused on the evolution (movement from the selfish "I" to the spiritual "I"). A person performs his professional activity not from any material incentives connected with the reward, but for the sake of improving the activity itself and, thus, self-actualizing and self-fulfilling in it.

The self-regulation in this case is conditioned by the person's value and meaningful orientations onto the fact that his or her professional activity brings benefit to people and society as a whole. The implementation of this activity can be perceived as an unselfish service to humanity. Such high aspirations of the individual, excluding the ambitious and material claims, automatically regulate the psycho-emotional state, social interaction (as these aspirations are based on high moral principles), serve as a powerful resource of intellectual and creative productivity.

It is necessary to highlight that there are no clear boundaries between the described levels, all the levels are interpenetrating, as the human psyche is an integral dynamic system.

Comparing the models and components of self-regulation considered in this article, it is possible to say that the proposed four-level model of self-regulation with respective self-regulatory capacities has similarities and differences regarding other models.

It is possible to see in the four-level model of self-regulation and the self-regulatory capacities a lot in common with respect to the components and levels in the other models: the self-regulation model, pointing out five levels: 1) biological, 2) emotional, 3) cognitive, 4) social, 5) prosocial (Shanker, 2012); the components of self-regulation: standards, monitoring, strength (energy), motivation, denoted by (Baumeister \& Vohs, 2007); the seven-level model of regulation (Kaschel \& Kuhl, 2004) etc., but in my both models all these components and levels are organized differently. The main difference is that I pick out and emphasize an additional spiritual level, which can transform all the other levels and ensure the immense positive strength or energy for self-regulation. 
It is important to highlight that the fourth spiritual level allows to activate powerful spiritual resources and decrease ego depletion. According to the strengths model of selfcontrol, "effortful self-regulation depends on a limited resource that becomes depleted by any acts of self-control, causing subsequent performance even on other self-control tasks to become worse" (Baumeister, Vohs, Tice, 2007, p. 351). Adding motivation to the other components of self-regulation R. Baumeister \& Vohs emphasize its important role to compensate or substitute other components to some degree. "If motivation is high, such as if the person really and strongly wants to measure up to some standard, this may compensate for a somewhat lower than usual level of willpower or a greater difficulty of monitoring" (Baumeister \& Vohs, 2007, p. 117). Thus, in relation to the four-level model of self-regulation and self-regulatory capacities, it is possible to say that if motivation can be associated with a higher spiritual level, its power increases even more and the resource of self-regulatory capacities becomes magnificent.

The proposed idea of an immense resource of the fourth spiritual level of self-regulation and higher self-regulatory capacities can receive support within the framework of "nonlimited resource theory", which, in contrast to "limited resource theory", states that if people believe that willpower is an extensive, abundant (rather than highly limited) resource, they show better self-control when they perform demanding tasks (Job, Dweck, Walton, 2010). This is confirmed by experimental studies. The experiments show that people's beliefs about the nature of willpower can limit or facilitate the acquisition of a cognitive skill (Miller et al., 2012); that people, using a non-limited theory of willpower, self-regulate well in the face of high demands (Job et al., 2015).

Thus, the implicit theories, concerning willpower, can help people's ability to reinforce their resources. The spiritual level of self-regulation related to unselfish service to people and society can intensify willpower and resources making them non-limited, contributing immensely to the effectiveness of life activity.

\section{Conclusion}

1. Basing on the theoretical analysis, it is possible to say that the self-regulation is described in the Western and Russian psychology as a human goal-oriented controlled activity as well as the ability to manage one's own psychological and physiological state. The self-regulation is studied in relation to the different facets of life: health management, well-being, self-regulated learning, professional activity, etc., focusing on different aspects: emotional, cognitive, motivational, behavioral.

2. Self-regulation is mostly represented through the term "capacity" or "ability". It makes the researchers take these terms into account more profoundly and describe the self-regulatory capacities in more detail.

3. Numerous components, levels and models of self-regulation show the interest of the researchers to study this complex phenomenon in different aspects. Such components as motivation, standards (values, morality), goal-setting, designing the necessary conditions to rich a goal, monitoring and self-control, evaluation and correction of results, capacity to show willpower and persist in goal attainment are general and crucial.

4. The suggested four-level model of self-regulation and the four-level model of selfregulation and self-regulatory capacities, unlike other models, include a higher spiritual 
level of self-regulation, which is related to higher moral principles and based on the highest values and meanings of being. Higher (spiritual) self-regulatory capacities help to move from egocentrism to the unselfish self, liberating the potential of energy for a disinterested selfless service to society. It can allow to increase immensely the energy resource of self-regulation and contribute to productivity and quality of human life.

\section{Acknowledgements:}

The study was supported by RSF grant (project № 18-18-00386), Institute of Psychology RAS.

\section{REFERENCES}

Anokhin, P.K. (1970). The Theory of functional system. Success of physiological science, 1(1).

Bandura, A. (1982). Self-efficacy mechanism in human agency. American Psychologist, 37, 122-147.

Bandura, A. \& Cervone, D. (1983). Self-evaluative and self-efficacy mechanisms governing the motivational effects of goal systems. Journal of Personality and Social Psychology, 45, 1017-1028.

Bandura, A. (1991a). Social cognitive theory of self-regulation. Organizational Behavior and Human Decision Processes, 50, 248-287.

Bandura, A. (1991b). Self-regulation of motivation through anticipatory and self-regulatory mechanisms. In R.A. Dienstbier (Ed.), Perspectives on motivation: Nebraska symposium on motivation, 38, 69164. Lincoln: Univ. of Nebraska Press.

Baumann, N., Kaschel, R., \& Kuhl, J. (2005). Striving for unwanted goals: Stressdependent discrepancies between explicit and implicit achievement motives reduce subjective well-being and increase psychosomatic symptoms. Journal of Personality and Social Psychology, 89, 781-799.

Baumeister, R.F., \& Vohs, K.D. (2007). Self-Regulation, Ego Depletion, and Motivation. Social and Personality Psychology Compass, (1), 115-128.

Baumeister, R., Schmeichel, B., \& Vohs, K. (2007). Self-Regulation and the Executive Function: The Self as Controlling Agent. In A. W. Kruglanski \& E.T. Higgins (Eds.), Social psychology: Handbook of basic principles (Second edition). New York, United States: Guilford Press, 516-539.

Baumeister, R., Vohs K.D., \& Tice D.M. (2007). The Strength Model of Self-Control. Current directions in psychological science. 16, 6, 351-355.

Berk, L.E. (2003). Child development. Boston, MA: Allyn and Bacon.

Bodrov V.A. (2006). Psychological stress: development and coping. Moscow: Per SE. (In Russ.).

Brief Dictionary of Psychological Terms. Retrieved from: https://vocabulary.ru/slovari/kratkii-slovarpsihologicheskih-terminov.html (In Russ.).

Cameron, D., Webb, Th. (2013). Self-Regulatory Capacity. Encyclopedia of Behavioral Medecine, 1757-1759. Retrieved from: https://link.springer.com/referenceworkentry/10.1007\% 2F978-1-4419-1005-9 1177

Carver, C.S., \& Scheier, M.F. (1998). On the self-regulation of behavior. Cambridge, UK: Cambridge University Press.

Cameron, L., \& Leventhal, H. (Eds.), (2003). The Self-regulation of Health and Illness Behaviour. American Psychological Associations.

Corno, L. (1989). Self-regulated learning: A volitional analysis. In B.J. Zimmerman \& D.H. Schunk (Eds.), Self-regulated learning and academic achievement: Theory, research, and practice (pp. 111141). New York: Springer.

Dictionary of Sociology. Retrieved from http://enc-dic.com/sociology/Samoreguljacija-8060.html (In Russ.). 
Diehl, M., Semegon, A.B., \& Schwarzer, R. (2006). Assessing attention control in goal pursuit: A component of dispositional self-regulation. Journal of Personality Assessment, 86, 306-317.

Dikaya, L.G. (2003). Mental self-regulation of a person's functional state. Moscow: Institute of Psychology Publ. (In Russ.).

Encyclopaedic dictionary: Psychology of labor, management, engineering psychology and ergonomics). Retrieved from: https://vocabulary.ru/slovari/110-enciklopedicheskii-slovar-psihologija-trudaupravlenija-inzhenernaja-psihologija-i-ergonomika.html (In Russ.).

Fischera, S., \& Munsch, S. (2012). Self-Regulation in Eating Disorders and Obesity - Implications for Treatment. (English Version of) Verhaltenstherapie, 22, 158-164. doi: 10.1159/000341540

Gollwitzer, P.M., Fujita, K., \& Oettingen, G. (2004). Planning and the implementation of goals. In R.F. Baumeister \& K.D. Vohs. (Eds). Handbook of Self-Regulation (pp. 211-228). New York: The Guilford Press.

Gonzalez, A.M. (2013). Six Principles of Self-Regulated Learning: Developing Self-Regulated Language Learners. Retrieved from: https://scholarsarchive.byu.edu/cgi/viewcontent.cgi?article = $5051 \&$ context $=$ etd

Gross, J.J. (2007). Handbook of Emotion Regulation. New York: The Guilford Press.

Gross, J.J., \& John, O.P. (2003). Individual differences in two emotion regulation processes: implications for affect, relationships, and well-being. Journal of Personality and Social Psychology, 85, 348-362.

Hofer, J., Busch, H., Kärtner J. (2011). Self-regulation and well-being: The influence of identity and motives. European Journal of Personality, 25, 211-224.

Hustad, J., Carey, K. Carey, M., \& Maisto, S. (2009). Self-Regulation, Alcohol Consumption, and Consequences in College Student Heavy Drinkers: A Simultaneous Latent Growth Analysis. Journal of Studies on Alcohol and Drugs, 70(3), 373-382.

Ivannikov, V.A. (2010). Volition. National Psychological Journal, 1(3), 97-102. (In Russ.).

Job, V., Dweck, C.S., \& Walton, G.M. (2010). Ego depletion - Is it all in your head? Implicit theories about willpower affect self-regulation. Psychological Science, 21, 1686-1693. doi: 10.1177/ 0956797610384745

Job, V., Walton, G.M., Bernecker, K., \& Dweck, C.S. (2015). Implicit Theories About Willpower Predict Self-Regulation and Grades in Everyday Life. Journal of Personality and Social Psychology, 108(4), 637-647. doi: 10.1037/pspp0000014

Karoly, P. (1993). Mechanisms of self-regulation: a systems view. Annual Review of Psychology, 44, $23-52$.

Kaschel, R., \& Kuhl, J. (2004). Motivational counseling in an extended functional context: Personality systems interaction theory and assessment. In W.M. Cox \& E. Klinger (Eds.), Motivational counseling: Motivating people for change (pp. 99-119). Sussex: Wiley.

Kent, M. (2006). Oxford Dictionary of Sports Science \& Medicine (3 ed.). Oxford: Oxford University Press.

Konopkin, O.A. (1995). Psychic Self-regulation of arbitrary human activity. Voprosy Psikhologii, (1), 7-12. (In Russ.).

Konopkin, O.A. (2007). The mechanisms of conscious self-regulation of voluntary activity of the person. In V.I. Morosanova (Ed.), Subject and personality in psychology of self-regulation. Moscow, Stavropol. PI RAO Publ., Sevkavgtu Publ., 12-31. (In Russ.).

Kuhl, J. (2000). The volitional basis of personality systems interaction theory: Applications in learning and treatment contexts. International Journal of Educational Research, 33, 665-703.

Kuhl, J. (2001). Motivation und Personlichkeit. Interaktionen psychischer Systeme [Motivation and personality: Interactions of mental systems]. Gettingen: Hogrefe. 
Kuhl, J., \& Koole, S.L. (2004). Workings of the will: A functional approach. In J. Greenberg, S.L. Koole, \& T. Pyszczynski (Eds.), Handbook of experimental existential psychology (pp. 411-430). New York: Guilford Press.

Kuhl, J., Kazén, M., \& Koole, S. (2006). Putting Self-Regulation Theory into Practice: A User's Manual. Applied Psychology, 55 (3), 408-418.

Miller, E.M., Walton, G.M., Dweck, C.S., Job, V., Trzesniewski, K.H., \& McClure, S.M. (2012). Theories of Willpower Affect Sustained Learning. In J.J. Geng (Ed.), PLoS ONE, 7(6), e38680. doi: 10.1371/journal.pone.0038680

Leonova, A.B. (2007). Mental reliability of the professional and contemporary technologies of stress management. Vestnik Moskovskogo Universiteta. Seriya 14. Psikhologiya, (3), 69-81. (In Russ.).

Leontiev, A.N. (1975). Activity. Consciousness. Personality. Moscow: Politizdat Publ. (In Russ.).

Morosanova, V.I. (1998). Individual style of self-regulation: the phenomenon, the structure and functions of human voluntary activity. Moscow: Nauka Publ. (In Russ.).

Mann, T., De Ridder, D., \& Fujita, K. (2013). Self-regulation of health behavior: Social psychological approaches to goal setting and goal striving. Health Psychology, 32(5), 487-498. doi: 10.1037/ a0028533

Mischel, W. \& Liebert, R.M. (1966). Effects of discrepancies between observed and imposed reward criteria on their acquisition and transmission. Journal of Personality and Social Psychology, (3), $45-53$.

Mischel, W. \& Ayduk, O. (2004). Willpower in a cognitive-affective processing system: the dynamics of delay of gratification. In R.F. Baumeister \& K.D. Vohs (Eds), Handbook of Self-Regulation (pp. 99-129). New York: The Guilford Press.

Ochsner, K.N., \& Gross, J.J. (2005). The cognitive control of emotion. Trends in Cognitive Science, 9 , $242-249$.

Osnitsky, A.K. (2000). The structure, content and functions of a regulatory experience of the person. Doctor Sc. in Psychology Thesis. Moscow: Institute of Psychology of Russian Academy of Sciences. (In Russ.).

Ozhiganova, G.V. (2010). Psychological aspects of spirituality: spiritual abilities. Psikhologicheskii Zhurnal, 31(5), 39-53. (In Russ.).

Ozhiganova, G.V. (2016). Spiritual capacities as a resource of life activity. Moscow: Institute of Psychology of Russian Academy of Sciences publ. (In Russ.).

Prokhorov, A.O. (2005). Self-regulation of mental states: phenomenology, mechanisms, laws. Moscow, PER SE. (In Russ.).

Prygin, G.S. (2009). Psychology of autonomy. Izhevsk, Naberezhnye Chelny, Institut upravleniya Publ. (In Russ.).

Ross, T. \& Fontao, M.I. (2006). Self-regulation and emotional experience: Preliminary findings in nonsexual and sexual offenders. Sexual Offender Treatment, 1(2). Retrieved from http://www.sexualoffendertreatment. org/17.0.html

Ross, T., \& Fontao, M.I. (2007). The relationship of self-regulation and aggression: An empirical test of Personality Systems Interaction Theory. International Journal of Offender Therapy and Comparative Criminology, 52(5). 554-570.

Ross, T., Fontao, M.I., \& Schneider, R. (2007). Aggressive behavior in male offenders: preliminary analyses of self-regulatory functions in a sample of criminals. Psychological Reports, 100, 11711185.

Rueda, M.R., Posner, M.I., \& Rothbart, M.K. (2011). Attentional control and self-regulation. In R.F. Baumeister, K.D. Vohs (Eds.), Handbook of self-regulation: Research, theory, and applications (pp. 284-299). New York, NY: Guilford Press. 
Shanker, S.G. (2012). Calm, Alert and Learning: Classroom Strategies for Self-Regulation. Pearson).

Schunk, D.H. (1985). Participation in goal-setting: Effects on self -efficacy and skills of learning disabled children. Journal of Special Education, 19, 347-369.

Schunk, D.H. (1990). Goal setting and self-efficacy during self-regulated learning. Educational Psychologist, 25, 71-86.

Schunk, D.H. (2001). Social cognitive theory and self-regulated learning. In B.J. Zimmerman and D.H. Schunk (Eds.), Self-regulated learning and academic achievement. (pp. 125-154). Mahwah: NJ: Lawrence Erlbaum Associates, Inc.

Schunk, D.H., \& Zimmerman, B.J. (1997). Social origins of self-regulatory competence. Educational Psychologist, 32, 195-208.

Stolin, V.V. (1985). Knowledge of self and attitude to the self in the self-consciousness structure. Doctor Sc. in Psychology Thesis. Moscow. (In Russ.).

Tittle, C.R., Ward, D.A., \& Grasmick, H.G. (2003). Self-control and crime/deviance: Cognitive vs. behavioral measures. Journal of Quantitative Criminology, 19, 333-365.

Zimmerman, B.J. \& Ringle, J. (1981). Effects of model persistence and statements of confidence on children's efficacy and problem solving. Journal of Educational Psychology, 73, 485-493.

Zimmerman, B., Bonner, S., \& Kovach, R. (1996). Goal 1: Understanding the principles of selfregulated learning. In Developing self-regulated learners: Beyond achievement to self-efficacy (pp. 5-24). Washington, D.C.: American Psychological Association.

Zimmerman, B.J. (2001). Theories of Self-Regulated Learning and Academic Achievement: An Overview and Analysis. In Zimmerman, B.J. \& Schunk, D.H. (Eds.), Self-Regulated Learning and Academic Achievement: Theoretical Perspectives (pp. 1-65). Mahwah, NJ: Lawrence Erlbaum Associates, Publishers.

Zimmerman, B.J. (2002). Becoming a self-regulated learner: An overview. Theory into Practice, 41(2), 64-70.

(C) Ozhiganova G.V., 2018

This work is licensed under a Creative Commons Attribution 4.0 International License

\section{Article history:}

Received 3 May 2018

Revised 14 June 2018

Accepted 16 July 2018

\section{For citation:}

Ozhiganova, G.V. (2018). Self-Regulation and Self-Regulatory Capacities: Components, Levels, Models. RUDN Journal of Psychology and Pedagogics, 15(3), 255-270. doi: 10.22363/2313-16832018-15-3-255-270

\section{Bio Note:}

Galina V. Ozhiganova - Ph.D. in Psychology, Senior researcher, Laboratory of psychology of abilities and mental resources named after V.N. Druzhinin, Institute of Psychology of Russian Academy of Sciences (Moscow, Russia). E-mail: symosium2016@rambler.ru 


\title{
САМОРЕГУЛЯЦИЯ И САМОРЕГУЛЯТИВНЫЕ СПОСОБНОСТИ: КОМПОНЕНТЫ, УРОВНИ, МОДЕЛИ
}

\author{
Г.В. Ожиганова \\ Институт психологии РАН \\ Российская Федерация, 129366, Москва, Ярославская ул., 13
}

\begin{abstract}
В статье рассматриваются разные определения саморегуляции. Приводятся представления о саморегуляции, сложившиеся в рамках зарубежной и отечественной психологии, которые показывают, что саморегуляция изучается в связи с разными аспектами жизнедеятельности: процесс обучения, профессиональная деятельность, благополучие, регулирование состояния здоровья и др. Саморегуляция в основном определяется с помощью термина «способность», что заставляет более глубоко осмыслить сам термин саморегулятивные способности. Теоретический анализ компонентов, уровней, моделей саморегуляции позволяет говорить об их разнообразии, но все же необходимо выделить общие ключевые компоненты: мотивацию; стандарты поведения (включая морально-ценностные ориентиры); выдвижение целей; проектирование условий, необходимых для достижения целей; способность к мониторингу процесса саморегуляции (самоконтроль); оценка и коррекция результатов; способность проявлять волю в достижении поставленных целей. Теоретический анализ различных компонентов, уровней, моделей саморегуляции показал, что в них отсутствует духовная составляющая. В этой связи автором были предложены две модели, включающие духовный аспект: а) четырехуровневая модель саморегуляции; б) четырехуровневая модель саморегуляции и саморегулятивных способностей. Обе модели содержат высший духовный уровень саморегуляции, связанный с ориентацией на высшие моральные принципы, высшие ценности и смыслы. Высшие саморегулятивные способности, соответствующие этому уровню, способствуют раскрытию духовного потенциала и мобилизации энергии для бескорыстного служения обществу. Это позволяет повышать энергетический ресурс саморегуляции в целом и создавать условия для улучшения качества жизни и продуктивной жизнедеятельности.
\end{abstract}

Ключевые слова: саморегуляция, компоненты и уровни саморегуляции, высший (духовный) уровень саморегуляции, высшие саморегулятивные способности, модели саморегуляции

\section{Благодарности и финансирование:}

Исследование выполнено при финансовой поддержке РНФ (проект № 18-18-00386), Институт психологии РАН.

\section{История статьи:}

Поступила в редакцию: 3 мая 2018

Принята к печати: 16 июля 2018

\section{Для цитирования:}

Ожиганова Г.В. Саморегуляция и саморегулятивные способности: компоненты, уровни, модели // Вестник Российского университета дружбы народов. Серия: Психология и педагогика. 2018. Т. 15. № 3. С. 255-270. doi: 10.22363/2313-1683-2018-15-3-255-270

\section{Сведения об авторе:}

Ожиганова Галина Валентиновна - кандидат психологических наук, старший научный сотрудник лаборатории психологии способностей и ментальных ресурсов Института психологии РАН (Москва, Россия). E-mail: symosium2016@rambler.ru 